\title{
Diabetic nephropathy among Type 2 Diabetes Mellitus patients in Dr. Cipto Mangunkusumo Hospital
}

\author{
H. M. S. Markum, Miko Galastri
}

\begin{abstract}
Abstrak
Nefropati diabetik telah diketahui merupakan salah satu penyulit jangka panjang diabetes melitus (DM) yang berbahaya, yang dapat menyebabkan kegagalan ginjal tahap akhir. Namun, data adanya nefropati diabetik di antara pasien diabetes tipe 2 yang menjalani rawat jalan saat ini belum ada. Penelitian cross-sectional ini ditujukan untuk mengetahui prevalensi nefropati diabetik di antara penderita diabetes tipe 2 rawat jalan yang datang untuk pertama kalinya ke Klinik Metabolik dan Endokrinologi, RSUPN Dr. Cipto Mangunkusumo, Jakarta. Dari Desember 2001 sampai Juni 2002, 100 pasien baru diabetes tipe 2 diikutsertakan dalam studi. Empat puluh dua di antaranya adalah laki-laki dengan usia rata-rata 54 + 9,6 tahun. Overt nephropathy (makroalbuminuria) ditemukan pada $11 \%$ pasien, incipient nephropathy (mikroalbuminuria) terdapat pada $26 \%$ penderita, sedangkan sisanya normal (normoalbuminuria). Hasil penelitian menunjukkan bahwa lama sakit yang lebih dari 5 tahun menunjukkan korelasi bermakna dengan derajat albuminuria. Namun, tidak ada hubungan bermakna antara derajat albuminuria dengan faktor-faktor risiko lain, yaitu usia, dislipidemia, hipertensi, obesitas, dan kadar $\mathrm{HbA}_{l} c$. Semua pasien dengan overt nephropathy menunjukkan tes klirens kreatinin di bawah $75 \mathrm{ml}$ menit (rerata 45,3 mL/menit), secara bermakna lebih rendah dari pasien dengan mikro- atau normoalbuminuria $(p=0,01)$. Retinopati ditemukan pada 10 dari 11 (90\%) pasien dengan overt nephropathy. Analisis multivariat memperlihatkan bahwa lama sakit dan retinopati secara bermakna berkorelasi dengan terjadinya nefropati diabetik ( $p<0,05)$. Sebagai kesimpulan dapat dikatakan bahwa prevalensi nefropati diabetik (yaitu overt nephropathy dengan retinopati) di antara pasien diabetes tipe 2 rawat jalan adalah 10\%. Lama sakit merupakan faktor risiko penting bagi timbulnya penyulit ini. (Med J Indones 2004; 13: 161-5)
\end{abstract}

\begin{abstract}
Diabetic nephropathy has been known as one of the most serious long-term complications of diabetes mellitus (DM), which could lead to end-stage kidney failure. However, data showing the presence of diabetic nephropathy among ambulatory type 2 diabetic patients is currently not available. This cross-sectional study was conducted to find the prevalence of diabetic nephropathy among nonhospitalized type 2 diabetic patients, who came for the first time to the Metabolic and Endocrinology Clinic, Dr. Cipto Mangunkusumo Hospital, Jakarta. From December 2001 to June 2002, 100 new type 2 diabetic patients were included in the study. Forty-two of them were men and the mean age was $54 \pm 9.6$ years. Overt nephropathy (macroalbuminuria) was found in $11 \%$ of patients, while incipient nephropathy (microalbuminuria) was $26 \%$, and the rest were normal (normoalbuminuria). Duration of illness of more than 5 years was significantly correlated with the degree of albuminuria. However, there is no significant correlation between the degree of albuminuria and other risk factors, i.e. patient's age, dyslipidemia, hypertension, obesity, $H b A_{1} c$ level. All patients with overt nephropathy had creatinine clearance test below $75 \mathrm{ml} / \mathrm{min}$. (mean $45.3 \mathrm{~mL} / \mathrm{min}$ ), significantly lower than patients with micro- or normoalbuminuria $(p=0.01)$. Retinopathy was found in 10 out of 11 (90\%) patients with overt nephropathy. Multivariate analysis showed that the duration of illness and retinopathy was significantly correlated with the presence of diabetic nephropathy $(p<0.05)$. We concluded that the prevalence of diabetic nephropathy (i.e. overt nephropathy with retinopathy) among non-hospitalized type 2 diabetic patients was $10 \%$. The duration of illness was an important risk factor for the development of this complication. (Med J Indones 2004; 13: 161-5)
\end{abstract}

Keywords: diabetic nephropathy, chronic kidney disease, diabetic retinopathy, albuminuria, ambulatory type 2 diabetic patients

Diabetic nephropathy is a clinical syndrome characterized by persistent albuminuria of more than $300 \mathrm{~mL} / 24$ hour

Division of Kidney-Hypertension, Department of Internal Medicine, University of Indonesia / Dr. Cipto Mangunkusumo Hospital, Jakarta, Indonesia and retinopathy without clinical signs of renal or urinary tract disturbance among Diabetics. ${ }^{1,2}$ The prevalence of type 2 diabetes mellitus (DM) patients who progress to diabetic nephropathy is 20-30\%. In September 1998, World Health Organization (WHO) estimated that the prevalence of type 2 DM patients will increase by $41 \%$, i.e. from 51 millions in 1995 to 92 millions in 2005 . 
Diabetic nephropathy is a leading cause of morbidity and mortality among type $2 \mathrm{DM}$ patients. If albuminuria present, there will be a reduction of $2-20 \mathrm{~mL} / \mathrm{min}$ of glomerular filtration rate (GFR) per year. ${ }^{1,2}$

Sitompul has reported that the prevalence of microalbuminuria and macroalbuminuria in type $2 \mathrm{DM}$ were $6.9 \%$ and $8.6 \%$, respectively. ${ }^{3}$ Hariyono found that the prevalence of microalbuminuria and macroalbuminuria were $31.3 \%$ and $4.4 \%$, respectively. Further observation showed that after 1.5 -year, $40.4 \%$ of the normoalbuminuria group became microalbuminuria, while in the group of microalbuminuria, $8.4 \%$ became macroalbuminuria. $^{4}$

Currently there is no data on the prevalence of diabetic nephropathy among type 2 diabetic patients in terms of the persistence of microalbuminuria or macroalbuminuria. Although Dr. Cipto Mangunkusumo Hospital is a referral hospital, many diabetic patients come without reference from other medical facilities. The objective of this study was to find the prevalence of diabetic nephropathy among type $2 \mathrm{DM}$ patients and its correlation with several clinical parameters that came to the Endocrinology-Metabolic Clinic for the first time, with or without reference from other medical facilities.

\section{METHODS}

\section{Patients}

This was a cross-sectional study conducted between December 2001 and June 2002. All new type 2 diabetic patients in the Endocrinology-Metabolic Clinic Dr. Cipto Mangunkusumo Hospital were included if they were willing to join the study. Patients with urinary tract infection, fever, heart failure or liver cirrhosis were excluded. Eligible patients underwent a thorough anamnesis, physical examination and laboratory testing which included urinalysis, blood chemistry, lipid profile and $\mathrm{HbA}_{1} \mathrm{c}$ level.

All patients then underwent quantitative albuminuria testing. Urinary dipstick test was done to detect albuminuria. Positive result with urinary albumincreatinine ratio $\geq 300 \mathrm{mg} / \mathrm{g}$ (macroalbuminuria) was designated as overt nephropathy. Urinary albumincreatinine ratio was also calculated in patients with negative result. If the value was between $30-300 \mathrm{mg} / \mathrm{g}$ (microalbuminuria), it is designated as incipient nephropathy. A value below $30 \mathrm{mg} / \mathrm{g}$ was designated normoalbuminuria. Persistent microalbuminuria was established if the patient showed positive microalbuminuria in the first and repeated tests. Patients with persistent microalbuminuria underwent funduscopy examination to find the presence of retinopathy in the Department of Ophthalmology.

\section{Risk factors}

Clinical data were obtained from the patients to assess risk factors, which contribute to microalbuminuria. They included the patient's age (below or above 40 years), duration of illness (more or less than 5 years), hypertension (blood pressure $\geq 140 / 90 \mathrm{mmHg}$ and/or with antihypertensive medication, JNC VI criteria), obesity (body mass index [BMI] $>25 \mathrm{~kg} / \mathrm{m}^{2}$, WHO criteria), dyslipidemia (total cholesterol $>200 \mathrm{mg} / \mathrm{dL}$ and/or triglyceride level > $150 \mathrm{mg} / \mathrm{dL}$, ATP III), $\mathrm{HBA}_{1} \mathrm{c}$ level, creatinine clearance test prediction (using the Cockroft-Gault formula) and the presence of retinopathy.

\section{Statistical Analysis}

Descriptive statistics was performed to patient characteristics and risk factors. Correlations between microalbuminuria and risk factors were tested using non-parametric test (Chi-square and KolmogorovSmirnov tests). A $p$ value below 0.05 was significant. Significant factors were further tested using multivariate analysis. All statistical analyses were done by statistical software system SPSS for Windows version 10.0.

\section{RESULTS}

There were 125 new type $2 \mathrm{DM}$ patients during the study period. From this number, 100 patients met the inclusion and exclusion criteria and eligible for the study. Eleven percents of the patients had macroalbuminuria, 25\% had microalbuminuria and the rest were normal. The demographic data of the patients were presented in Table 1.

The correlation between diabetic nephropathy and its risk factors is presented in Table 2. There was a correlation between the duration of illness and the presence of diabetic nephropathy. However, there was no correlation between diabetic nephropathy and the concentration of $\mathrm{HbA}_{1} \mathrm{c}$, body mass index, total cholesterols, triglyceride level and hypertension. 
Predictive calculated creatinine clearance test (CCT) among patients is presented in Table 3. The lowest CCT was found in patients with overt nephropathy (macroalbuminuria). There is a significant difference among the three groups of patients although the CCT was almost similar in patients with normoalbuminuria and microalbuminuria.

Retinopathy was found in 24 (24\%) patients. Three out of 60 patients in normoalbuminuria group has already developed nephropathy. In contrast, only one patient with overt nephropathy did not show retinopathy. The difference is very significant (Table 4).

Table 1. Patient Characteristics

\begin{tabular}{|c|c|c|}
\hline Variable & $\begin{array}{l}\text { Frequency } \\
(\mathrm{n}=100)\end{array}$ & $\begin{array}{c}\text { Percentage } \\
(\%)\end{array}$ \\
\hline \multicolumn{3}{|l|}{ Sex } \\
\hline Male & 42 & 42 \\
\hline Female & 58 & 58 \\
\hline \multicolumn{3}{|c|}{ Age $($ mean $54 \pm 9.6)$} \\
\hline$\geq 40$ years & 91 & 91 \\
\hline$<40$ years & 9 & 9 \\
\hline \multicolumn{3}{|c|}{$\begin{array}{l}\text { Mean duration of DM (range: } \\
0.05-23 \text { ) }\end{array}$} \\
\hline$\geq 5$ years & 36 & 36 \\
\hline$<5$ years & 64 & 64 \\
\hline \multicolumn{3}{|c|}{ Total cholesterol (mg/dL) } \\
\hline$\geq 200$ & 75 & 75 \\
\hline$<200$ & 25 & 25 \\
\hline \multicolumn{3}{|c|}{ Triglycerides (mg/dL) } \\
\hline$\geq 150$ & 46 & 46 \\
\hline$\overline{<} 150$ & 54 & 54 \\
\hline \multicolumn{3}{|c|}{ Hypertension } \\
\hline Yes & 39 & 39 \\
\hline No & 61 & 61 \\
\hline \multicolumn{3}{|c|}{ Body Mass Index } \\
\hline Obese & 22 & 22 \\
\hline Not obese & 78 & 78 \\
\hline \multicolumn{3}{|l|}{ HbA1c $(\%)$} \\
\hline$\geq 7$ & 73 & 73 \\
\hline$<7$ & 27 & 27 \\
\hline \multicolumn{3}{|c|}{ Creatinine clearance test } \\
\hline$<75$ & 41 & 41 \\
\hline \multicolumn{3}{|l|}{$\geq 75$} \\
\hline \multicolumn{3}{|c|}{ Retinopathy } \\
\hline Yes & 24 & 24 \\
\hline No & 76 & 76 \\
\hline
\end{tabular}

$\mathrm{DM}=$ diabetes mellitus
Table 2. Factors related to albuminuria

\begin{tabular}{|c|c|c|c|c|}
\hline Variable & $\begin{array}{l}\text { Normo- } \\
\text { albuminuria } \\
(\mathrm{n}=63)\end{array}$ & $\begin{array}{c}\text { Micro- } \\
\text { albuminuria } \\
(\mathrm{n}=26)\end{array}$ & $\begin{array}{c}\text { Macro- } \\
\text { albuminuria } \\
(\mathrm{n}=11)\end{array}$ & $\begin{array}{c}p \\
\text { value }\end{array}$ \\
\hline \multicolumn{5}{|l|}{ HbA1c (\%) } \\
\hline$\geq 7$ & 45 & 19 & 9 & \multirow[t]{2}{*}{$0.77 *$} \\
\hline$<7$ & 18 & 7 & 2 & \\
\hline \multicolumn{5}{|l|}{ BMI } \\
\hline Obese & 12 & 7 & 3 & \multirow{2}{*}{$0.64 *$} \\
\hline Not obese & 51 & 19 & 8 & \\
\hline \multicolumn{5}{|l|}{ Age (years) } \\
\hline$>40$ & 57 & 23 & 11 & \multirow[t]{2}{*}{$0.54^{\#}$} \\
\hline$\leq 40$ & 6 & 3 & 0 & \\
\hline \multicolumn{5}{|l|}{ Total cholesterol } \\
\hline & $\begin{array}{l}47 \\
16\end{array}$ & $\begin{array}{c}21 \\
5\end{array}$ & 7 & \multirow{2}{*}{$0.54^{*}$} \\
\hline $\begin{array}{l}\geq 200 \mathrm{mg} / \mathrm{dL} \\
<200 \mathrm{mg} / \mathrm{dL}\end{array}$ & & & & \\
\hline \multicolumn{5}{|l|}{ Triglycerides } \\
\hline $\begin{array}{l}\geq 150 \mathrm{mg} / \mathrm{dL} \\
<150 \mathrm{mg} / \mathrm{dL}\end{array}$ & 36 & 11 & 7 & $0.35^{*}$ \\
\hline \multicolumn{5}{|l|}{ Hypertension } \\
\hline Yes & 20 & 13 & 6 & \multirow[t]{2}{*}{$0.09^{*}$} \\
\hline No & 43 & 13 & 5 & \\
\hline Duration of & 15 & 15 & 6 & \multirow[t]{2}{*}{$0.00 *$} \\
\hline $\begin{array}{l}\geq 5 \text { years } \\
<5 \text { years }\end{array}$ & 48 & 11 & 5 & \\
\hline \multicolumn{5}{|c|}{$\begin{array}{l}B M I=\text { body mass index; } D M=\text { diabetes mellitus; } \\
* \text { using Chi-square test } ;{ }^{\#} \text { using Kolmogorov-Smirnov test. }\end{array}$} \\
\hline \multicolumn{5}{|c|}{$\begin{array}{l}\text { Table 3. Calculated creatinine clearance test (CCT) based on } \\
\text { the degree of albuminuria }\end{array}$} \\
\hline $\begin{array}{l}\text { Calculated } \\
\text { CCT }\end{array}$ & $\begin{array}{l}\text { Normo- } \\
\text { albuminuria }\end{array}$ & $\begin{array}{c}\text { Micro- } \\
\text { albuminuria }\end{array}$ & $\begin{array}{c}\text { Macro- } \\
\text { albuminuria }\end{array}$ & $p$ value \\
\hline$<75 \mathrm{~mL} / \mathrm{min}$. & 32 & 13 & 11 & 0.008 \\
\hline$\geq 75 \mathrm{~mL} / \mathrm{min}$ & 31 & 13 & 0 & \\
\hline $\begin{array}{l}\text { Mean CCT } \\
(\mathrm{ml} / \mathrm{min} .)\end{array}$ & $80.4 \pm 39.1$ & $77.3 \pm 30.0$ & $45.3 \pm 15.1$ & 0.011 \\
\hline
\end{tabular}

Table 4. Diabetic retinopathy

\begin{tabular}{lcccc}
\hline Retinopathy & $\begin{array}{c}\text { Normo- } \\
\text { albuminuria } \\
(\%)\end{array}$ & $\begin{array}{c}\text { Micro- } \\
\text { albuminuria } \\
(\%)\end{array}$ & $\begin{array}{c}\text { Macro- } \\
\text { albuminuria } \\
(\%)\end{array}$ & $p$ value \\
\hline Yes & 3 & 11 & 10 & 0.000 \\
No & 60 & 15 & 1 & \\
\hline
\end{tabular}

\section{DISCUSSION}

Our study found that albuminuria occurred in $37 \%$ of patients, i.e. $26 \%$ with microalbuminuria or insipient nephropathy and $11 \%$ with macroalbuminuria or overt nephropathy. These findings were quite similar to 
other studies. Viberti et $\mathrm{al}^{5}$, Varghese et $\mathrm{al}^{6}$ and Parving et $\mathrm{al}^{7}$ found that macroalbuminuria was present in $16 \%, 6.9 \%$, and $13.8 \%$ of diabetic patients, respectively, whereas Savage et $\mathrm{al}^{8}$ found that the prevalence of microalbuminuria was between $25-36 \%$.

Risk factors analysis did not show significant correlation to the prevalence of diabetic nephropathy, except the duration of illness. It is probably due to the design of our study, which was cross-sectional rather than a prospective study. However, many investigators also found no correlation among diabetic nephropathy and several risk factors. Varghese et al, did not find any correlation between body mass index and the prevalence of diabetic nephropathy. ${ }^{6}$ Schmitz et al ${ }^{9}$ did not find a significant correlation between $\mathrm{HbA}_{1} \mathrm{c}$ level and the prevalence of diabetic nephropathy. Despite the fact that hypertension contribute to the progression of diabetic nephropathy, a study performed in Mayo Clinic did not find a correlation between hypertension and proteinuria or chronic renal failure. ${ }^{10}$

Duration of illness is an important factor for the development of diabetic nephropathy. Our current study found that albuminuria occurred in $60.6 \%$ patients who had suffered for more than 5 years, but only $25.4 \%$ in patients who had the disease less than 5 years (Table 2). This figure was very high. Several studies reported previously that the incidence of proteinuria below 5 years of illness is $7-10 \%$ and after 20-25 years, the number increased to $20-35 \%$. Another report also showed that the occurrence of proteinuria was $17 \%$ after 15 years of illness. ${ }^{11,12,13}$

All patients with overt nephropathy had predictive calculated CCT below $75 \mathrm{~mL} / \mathrm{min}$. Diabetic nephropathy could reduce renal function due to glomerulosclerosis, tubulointerstitial atrophy and this condition will decrease the glomerular filtration rate. Davies et $\mathrm{al}^{14}$ reported a clear relationship between nephropathy and reduced GFR among diabetic patients, which has suffered for 8 to1 1 years.

The presence of diabetic nephropathy implies that there is a systemic endothelial dysfunction, including in the retina. However, not all patients with diabetic nephropathy would develop retinopathy. We found that $24 \%$ patients presented with retinopathy, and $90 \%$ of patients with overt nephropathy had retinopathy. This finding is quite similar to a study by McKay ${ }^{15}$ who found that the prevalence of retinopathy is $29.1 \%$. Parving et al also reported that $76 \%$ patients with diabetic nephropathy had retinopathy. ${ }^{7}$

\section{CONCLUSION}

This study found that the prevalence of macroalbuminuria and microalbuminuria were $11 \%$ and $26 \%$, respectively, in non-hospitalized type 2 diabetic patients who came to Dr. Cipto Mangunkusumo Hospital for the first time. Diabetic nephropathy, i.e. overt nephropathy with retinopathy was observed in $10 \%$ of patients. There was a significant correlation between the presence of diabetic nephropathy and duration of diabetes mellitus.

\section{REFERENCES}

1. Hovind P, Rossing P, Tarnow L, Smidt UM, Parving HH. Progression of Diabetic nephropathy. Kidney Int 2001;59:702-9.

2. Trevisan R, Viberti G. Pathophysiology of diabetic nephropathy. In Le Roith D, Taylor SI, Olefsky JM, editors. Diabetes Mellitus. 2nd ed. Lippincot Williams \& Wilkins, Philadelphia, 2000; 902-10.

3. Sitompul R. Albuminuria pada penderita NIDDM dan hubungannya dengan berbagai keadaan klinis. Makalah akhir Program Studi Ilmu Penyakit Dalam, Program Pendidikan Dokter Spesialis I FKUI, Jakarta, 1991.

4. Hariyono. Mikroalbuminuria pada NIDDM: Faktor-faktor yang mempengaruhi perkembangannya. Makalah akhir Program Studi Ilmu Penyakit Dalam, Program Pendidikan Dokter Spesialis I FKUI, Jakarta 1994.

5. Viberti G, Wiseman MJ, Pinto JR, Messent J. Diabetic nephropathy. In: Kahn CK, War CG, editors. Joslin diabetes mellitus 13th ed. Lea \& Febringer, Philadelphia, 1994: 691-737.

6. Varghese A, Deepa R, Rema M, Mohan V. Prevalence of microalbuminuria in type 2 diabetes mellitus at a Diabetes Centre in Southern India. Postgrad Me J 2001: 399-402.

7. Parving HH. Diabetic nephropathy: prevention and treatment. Kidney Int 2001;60:2041-55.

8. Savage S, Johnson N, Estacio RO, Lukken N, Schrier RW. Clinical factors associated with urinary albumin excretion in type II diabetes. Am J Kidney Dis 1995; 25: 836-44.

9. Schmitz A. Microalbuminuria, blood pressure, metabolic control, and renal involvement. Am J Hypertension 1997;10:S189-97.

10. Deedwania PC. Hypertension and diabetes. Arch Intern Med 2000;160:1585-93.

11. Park JY, Kim HK, Chung YE, Kim SW, Hong SU, Lee $\mathrm{KU}$. Incidence and determinants of microalbuminuria in Koreans with type 2 diabetes. Diab Care 1998;21:530-4.

12. Mohan V, Meera R, Premalatha G, Deepa R, Miranda P, Rema M. Frequency of proteinuria in type 2 diabetes mellitus seen at a Diabetes Centre in Southern India. Postgrad Med 2000;76:569-73.

13. Gall MA, Hougard P, Johnsen KB, Parving HH. Risk factors for development of incipient and overt diabetic nephropathy in patients with non-insulin dependent 
diabetes mellitus: prospective, observational study. BMJ 1997;314:783-8.

14. Davies L, Wilmhurst EG, Elduff, Funton J, Bligh PC, Fulcher GR. The relationship among homocysteine, creatinine clearance, and albuminuria in patients with type 2 diabetes. Diab Care 2001;24:1805-9.
15. McKay R, McCarty C, Taylor H. Diabetic retinopathy in Victoria, Australia: the visual impairment project. Br J Ophthalmol 2000;84:865-70. 